\title{
Review
}

\section{Songs of the Living Dead}

\section{CHRISTOPHER MORRIS}

Richard Dellamora and Daniel Fischlin, eds. The Work of Opera: Genre, Nationhood, and Sexual Difference. New York: Columbia University Press, 1997. $\mathrm{xi}, 350 \mathrm{pp}$.

Roger Parker and Mary Ann Smart, eds. Reading Critics Reading: Opera and Ballet Criticism in France from the Revolution to 1848. Oxford: Oxford University Press, 2001. x, 271 pp.

Carolyn Abbate. In Search of Opera. Princeton: Princeton University Press, 2001. xvi, 290 pp.

Mladen Dolar and Slavoj Žižek. Opera's Second Death. New York: Routledge, 2002. ix, 235 pp.

If Mladen Dolar and Slavoj Žižek are to be believed, opera is a double zombie. Stillborn as a concept from the very beginning and never "in accord with its time," opera endured a second death when the twentieth century lost faith in it as a viable and independent cultural form (pp. vii-ix). It lives on, of course, but is it nothing more than an artifact sustained by bloated cultural institutions and media technology? Does the living flesh of performance merely disguise its nostalgic preservation?

This inherent doubleness, this living death, was very much in evidence last December when the Royal Opera, Covent Garden, presented Sophie's Choice, a new opera based on the novel by William Styron with music by Nicholas
Maw. A much-hyped prestige project, it was directed by Trevor Nunn (former director of the National Theatre) and conducted by Simon Rattle, who described it as "the most significant British opera of the last 50 years." 1 The media were buzzing, seats were completely sold out in advance (unprecedented for contemporary opera), and concerns in the press about the prospect of representing the Holocaust on stage seemed to be a sign of healthy public debate and perhaps a confirmation that opera, though problematic, was at least still relevant. ${ }^{2}$

But critical reaction to the premiere soon quelled the hype. When the critic of the Neue Zürcher Zeitung likened Maw's score to film music and detected multiple references to Elgar and Britten, he articulated a widely expressed view of the music as superficial pastiche and of Sophie's Choice as a derivative and opportunistic opera of the film of the book. ${ }^{3}$ Critics were

\footnotetext{
${ }^{1}$ Anna Picard, review of Sophie's Choice, in Independent (8 Dec. 2002).

${ }^{2}$ Anticipating the premiere, Peter Conrad argued that, with appropriate care and sensitivity, it ought to be possible to represent Auschwitz on the operatic stage. "Singing the Unspeakable," Observer (17 Nov. 2002).

3Peter Hagmann, "Filmmusik, zweite Auflage," Neue Zürcher Zeitung (10 Dec. 2002). Anthony Holden described Maw's "pastiche" as "echoing every late-twentieth-century tonalist you care to name." "A Few Choice Words for Maw," Observer (15 Dec. 2002).
} 
also quick to remind readers that ticket prices for this production had been slashed (the most expensive seats had been capped at $£ 50$, one third of their normal price). There were also reports of considerable "intermission attrition" for this four-hour opera. As for the issue of representing the Holocaust, the problem for some critics was not just theatrical representability-Tim Ashley complained that "the sight of Auschwitz being flown in on a crinkly backcloth is as offensive as it is risible"4-but political representation, an issue that had dogged the Royal Opera House for some time. Throughout the late 1990s this centerpiece of the British establishment had come under heavy fire from the government and the media for its exorbitant ticket prices, its elitist, dysfunctional administration (the subject of a memorable "reality-TV" documentary ${ }^{5}$ ), and above all its successful application for National Lottery funding for a large-scale renovation, an award that moved the national press to wonder why public money intended for charities and good causes was being directed to a playpen for the rich. So when Anthony Holden drew attention to the "obscene" incongruity between the horror and deprivation being staged and the conspicuous wealth and privilege of its "blacktied" audience, he touched a raw nerve. ${ }^{6}$

Locally volatile as they are, these issues also have extraordinarily wide resonance, not only geographically but historically. As an impossible bundle of contradictions, opera has always seemed to challenge and problematize even the most elementary attempts at interpretation, let alone any neat reduction or grand theorization. In its profusion of means and media, in its propensity for generating cultic en-

\footnotetext{
${ }^{4}$ Review of Sophie's Choice, in Guardian (9 Dec. 2002). ${ }^{5}$ The House, directed by Michael Waldman (BBC television, 1996).

${ }^{6}$ Holden wrote: "I found it obscene for black-tied toffs [British slang for the aristocratic elite] to be admiring Nunn's sleek staging of the train to the concentration camp-full of a dully mourning chorus sporting designer yellow stars-and no doubt wondering whether it cost as much as the car in [the concurrently running stage production of] Chitty Chitty Bang Bang." The critic of Le Monde, meanwhile, complained of "melodramatic exploitation of this subject." Renaud Machart, "Sophie's Choice ou la difficulté de mettre le mal en musique," Le Monde (9 Dec. 2002).
}

thusiasm and its refusal to die a dignified death, opera mocks its critics and defies scholarly hubris. If ever a field of inquiry justified postmodern doubt, it is the study of opera. But this only seems to have offered the proverbial candle to moths, who succumb to a lure that shows no signs of diminishing. Opera's precarious and paradoxical existence continues to stimulate an extraordinary wealth of thought. And as operatic scholarship has shifted its focus from operatic "works" to performance, and from traditional notions of text to practice, the stakes seemed to have been raised. For there is now a sense that the one-way relationship between academic theory and cultural practice might be challenged, that theory might find new ways to intervene in the performance and reception of opera.

\section{Spectacle ANd IDeOlogy}

This is the stated aim of The Work of Opera: Genre, Nationhood, and Sexual Difference, an interdisciplinary collection of essays ranging historically from the seventeenth to the late twentieth century. It proposes what the jacket blurb boldly describes as "seminal re-readings . . . that will reinvent how operatic spectacles are read, perceived, and performed." A tall order indeed, and yet, marketing hype notwithstanding, there is something exciting about this ambitious claim. If the collection is necessarily doomed to fall short of such a spectacular promise, it opens up some remarkable territory, and it does so with considerable élan. That the editorial introduction by Richard Dellamora and Daniel Fischlin occasionally struggles to draw the various threads of the collection together is less a weakness than a sign of the book's diversity and richness; like opera, it is an untidy combination, and better for it.

I am aware, of course, that several years have passed since The Work of Opera was published, and many of the essays in the collection seem to have originated several years before that. Much has been written more recently on many of the issues addressed here, but it would be arrogant to suggest that musicology had "moved on," as though the book's central concernsopera's capacity both to reinforce and to disrupt normative structures and hierarchies, and 
particularly the interaction of ideologies of nationhood, gender, and sexuality-had been sufficiently explored or theorized.

Dellamora and Fischlin are careful not to oversimplify opera's mobilization of ideology as though its performative capacity rested on its coherence and wholeness. They stress, rather, that it is opera's very instabilities and gaps as a cultural practice that signal its reciprocal engagement with the formation and negotiation of social and political identity. So, for example, opera's material overdeterminationthe quantity of labor and wealth of cultural resources required to produce this unwieldy combination of media-demands and in turn signifies a privileged place within establishment culture. At the same time, however, the extent of its material consumption and display opens opera to the contingencies of production and consumption: "Because the meaning of materiality is fraught with the arbitrariness of hermeneutic systems, of the specificities of local time and place, of the conditions of performance, reception, and so forth, opera is also the site of important contestations about meaning" (p. 6). These contestations can take many forms, but crucial to the project of the book is that opera's construction of normative (implicitly masculine, heterosexual) national subjectivities has always been vulnerable to the return of the otherness it seeks to contain or dispel.

As several of the essays in the collection demonstrate, opera's "fraught" materiality opens it up to subversive enactments of sexualities and gender roles that may not be authorized by the official cultures in which opera is produced and consumed. As performed medium, it stages (literally and figuratively) alignments and differences not always openly avowed. Patricia Juliana Smith, for example, explores the implications and limits of "romantic friendship" between women in Bellini's Norma and Verdi's Aida, and Jim Ellis questions standard themes in the criticism of Britten's operas (establishment conservatism, obsession with sexuality and innocence in children), asking whether there is not something more "productive" there, an "ethical project ... that protested the sacrifice of youth in the name of a heterosexual nation" (p. 293). Tying these and many of the essays together is a thoroughly dialectical understanding of the relationship of sexual difference and nation. As the editors argue, the "genderedness of national identities" is matched by the "erotics of nation" (p. 4). This seems to go beyond the suggestion that sexual difference is intertwined with the concept of nationhood to the potentially problematic notion of specifically national (i.e., French, German, American) sexual and gendered identities. If this risks essentializing national difference, it also implies that sexuality and gender cannot be understood as universals that easily transcend or override nationhood. Rather, the editors seem to suggest the terms are dialectically intertwined so that neither is privileged: sexual identity and gender roles can be inflected and regulated by national difference (just as Western and non-Western sexualities may differ), yet the very emergence of these national identities and their attendant norms already depends in part on the formation of the sexualized, gendered subject. And although this may open up the possibility of performative realignments of hegemonic culture, Dellamora and Fischlin seem more attuned to a critical position, articulated in several of the essays, that focuses less on opera's emancipatory potential than on its repressive and regulatory mechanisms, its mobilization in the interests of national and gendered order (p. 4). In this reading, opera as text and cultural practice is presented as a potent vehicle of national, official ideology.

Dellamora and Fischlin offer, for example, a qualification of Adorno's claim in his Introduction to the Sociology of Music that "since the mid-nineteenth century a country's music has become a political ideology by stressing national characteristics, appearing as a representative of nation, and everywhere confirming the national principle." If the implication here is that music becomes associated with nationalism, the editors stress that the very ideology of "nation" is itself dependent on the "material and performative dimensions" of "symbolic practices" such as music (p. 3). Ideology is front and center again when, gesturing toward Walter Benjamin, they define the "work of opera" as the "the work of ideology transumed by aesthetics into the phantasma- 
goria, the spectacle, of a false consciousness" (p. 6). A persuasive illustration of this argument is to be found in the editors' skeptical reading of opera's queer politics. As much as they value the capacity of opera to challenge a heterosexual normativity and figure sexual difference in powerfully sensual and imaginative forms, they conclude that the issue of otherness as "spectacle" needs to be taken into account. Is there not something containing, manipulative and centering, they argue, in the configuration of difference as a spectacle, as opportunity to "display the allure of the heterogeneous, the differend that will not be eradicated, the queer" (p. 11)?

At stake here is the formation of the "political subject." Opera's ability to suspend disbelief rests, the editors argue, on a form of "mimetic idealism," but the "hyperbole and sheer egregiousness of the spectacle" challenge that suspension beyond its breaking point. In this "deformation" and reshaping of subjectivity, the spectacle mirrors the mechanisms of (mis)identification by which the nation produces its subjects: "The vox populi is given heroic proportion even as the spectacle of that proportion reenacts the political relations between ruler and ruled, conductor and performer, all conjoining to produce the work of nation and of opera" (p. 7). The emphasis here on a process of interpellation and misrecognition suggests Althusser, and it raises the question, often posed with regard to Althusser's theory of ideology, whether there is any possibility of resistance. To what extent do the gaps and inconsistencies pointed out by the editors destabilize opera's mobilization of ideology, undermining the persuasive force with which, to use Althusser's terminology, it hails its subjects?

\section{Mirrors and Circles}

For Susan McClary, the textual openness of Carmen presents a fundamental challenge to the critic: how to read the opera as text without implying a coherence and consistency that it repeatedly refuses (p. 128). Her response is to mirror the textual gaps by destabilizing and decentering her own reading, and this is done with a considerable degree of candor: far from tying up loose ends, the final paragraphs of her essay unravel any false authority or security. Crucially, she extends the "text" of the opera to embrace its consumption, asking how meaning has been constructed in the process of reception. It is not enough, she argues, to seek ideologies of "class, race and gender" in Bizet's music or Mérimée's novella. What must be examined as well are the terms of our own engagement, our continuing investment in the opera's politics of "identity and difference." Read in this way, she concludes, the value of Carmen might lie in its capacity to offer a mirror, exposing the strange conflict of allure and repulsion in our relationship with the Other and resituating the borders of the "self." Resistance here would be located in a conscious (re)appropriation of the ideologies embedded and reinforced in this broader text.

That this might be possible-that critique might allow us to intervene in our own engagement with opera, in turn transforming us-is a tantalizing prospect, yet it also gestures toward an impossible kind of self-awareness, a version of picking ourselves up by our own bootstraps. As Dellamora and Fischlin point out, mirrors are difficult to manipulate: exposing the "bourgeois self-identification" (p. 7) that fuels opera depends on our ability to isolate what it is in the reflection that distorts, as though we could transcend ourselves as source of the reflection. The risk is that we merely relocate the distortion and compound its effects by claiming selfawareness. The value here, though, might be not so much an imagined end result (or problematic claims made on its behalf) but the articulation of an unsettling process.

Tackling "the case of Wagner," Lawrence Kramer addresses a similar question: why, when we are so aware of Wagner's "dire ideologies" (p. 152), do we continue to enjoy music drama? At issue here is the experience of cardinal Wagnerian moments-the love scene on Brünnhilde's rock, Brünnhilde's immolationand Kramer parallels McClary in locating resistance in a mode of engagement, a way of hearing and understanding (in this case, Nietzsche's) that holds the potential for departing from hegemonic interpretative practices, whether the enthralled fetishization by Wagnerians past and present, or the sober "apolitical" whitewash- 
ing characteristic of much traditional analysis of Wagner's music. Kramer's answer begins with the psychoanalytic understanding of enjoyment not as opposed to repulsion, but as intimately related to it. Rather than negate or overcome the ideologies of the Ring, Wagner's music "yields on our behalf to their allure" and carries that allure beyond its breaking point, "releas[ing] an even stronger allure than the dire one lost" (p. 152). Critical here is the suggestion that the secret allure is not somehow overcome or neutralized, but intensifies to the point at which it betrays itself: "We do not have to forget the direness to enjoy the music; we enjoy the most when we best and most cunningly remember" (pp. 152-53). Kramer theorizes the climax of this ambiguous allure as jouissance, with its implications of both pleasure and pain, of liminal experience and radical reorientation of the self. What appeals to Kramer in this account of the Wagner experience is the possibility that sexuality might be uncoupled from the ideological discourses with which it is otherwise performatively entwined, and that this reconfiguration might disseminate its effects well beyond the limits of the scenes that set it in motion. The result would be a shattering of "the mirror in which nationalist or other ideologies reflect, and so support themselves upon, sexual desire-the mirror in which such ideologies thereby constrain and normalize sexual desire" (p. 155). This, he argues, would account for our investment in Wagner; what it represents is a Ring (Brünnhilde's Ring!) that initiates an experience despite itself.

One of the standard charges leveled against psychoanalytic theory is that it stages a retreat into a distortedly individualized psyche. Does Kramer's trajectory-from "dire" nationalist and racial ideologies to jouissance-represent such a retreat, an accusation directed at Kramer's contribution to Siren Songs: Representations of Gender and Sexuality in Opera in Mary Ann Smart's editorial introduction. ${ }^{7}$ I

${ }^{7}$ Mary Ann Smart, intro. in Siren Songs: Representations of Gender and Sexuality in Opera, ed. Smart (Princeton: Princeton University Press, 2000), p. 14. Lawrence Kramer, "Opera: Two or Three Things I Know about Her," in Siren Songs, pp. 186-203. would argue that Kramer's decisive gesture in The Work of Opera is to make the return journey, relating the transformative potential of individual, psychic experience back to an overtly social sphere. What he posits is a reappropriation of Wagner's model of community so that the heroic Volk becomes "despite itself, a denationalized polity" and Wagner's passive monads come to embody an intersubjectivity that is both desiring and vulnerable, united and divided (p. 157).

If McClary seeks to reposition the ideological mirror, Kramer imagines an engagement that turns the mirror into shards, reflecting multiple pleasurable images. The danger is that this investment in the transfiguring potential of jouissance might license ideas of transcendence and transfiguration that issue from and in turn reinforce the ideological framework that is supposed to have been disrupted and shattered. Despite Kramer's careful qualification drawing attention to the danger of "mystify[ing] sexuality," I am not convinced that his strategy of aligning jouissant experience with a release capable of "disrupting all normalizing structures" adequately distinguishes itself from the sort of aestheticized (and thoroughly eroticized) redemption toward which Wagner aimed (p. 156). ${ }^{8}$ And yet, as with McClary's essay, we might ask what Kramer's strategy opens up. Both authors gesture toward a textuality that encompasses a thorough interdependency of work and reception. They mine traditional notions of text (as score, libretto, narrative, and so forth), but extend those notions to embrace the reciprocal production of meaning through the consumption of performance. There is an important circularity here: McClary's essay opens with a mise-en-abime of spectatorship (soldiers "calculated to sound like 'us'" [p. 115]) and closes with spectatorial reappropriations of institutionalized meaning; Kramer begins with highly personal readings of the Ring (Nietzsche's and his own earliest experiences) and ends with an audience config-

\footnotetext{
${ }^{8}$ For all its virtuosity, Kramer's account of the origins of "performance" as a willed gesture somewhere between instinctual urge and the sublimation of that urge strikes me as a problematic idealization of the aesthetic. See Siren Songs, pp. 137-39.
} 
ured by the Ring. That is, the process imagined in both cases is not one in which we have first a fixed, historically determined work and then the variable deflections of its reception history, but the production of a text-and of meaningin an interaction that is in motion from the very beginning. In this sense they open up a productive space for the material and the contingent, for that fraught materiality that the editors so rightly identify.

\section{Critical Consequences}

Issues of reception, materiality, and meaning are highlighted in a more recent collection of essays centered on grand opera and ballet in Paris. As a critical exploration of journalistic criticism, Reading Critics Reading: Opera and Ballet Criticism in France from the Revolution to 1848 certainly represents a contribution to the burgeoning field of nineteenth-century reception history. But it sets out to do more than this, and it in fact issues a challenge to some of the prejudices and entrenched methodologies in the field of operatic reception history. One of the problems the collection identifies in established musicological practice is the tendency to treat journalistic criticism merely as documentary evidence, as a kind of historicizing appendage that relates information about events, conditions, political and cultural climates, and so on. Typically, a review might be cited to gauge the success of a premiere, to offer glimpses of the "shock of the new" or to flesh out a cultural context, often with the aim of contrasting an opera's troubled genesis with its subsequent triumphant career. Implicit in these essays is the desire to reassess this attitude to criticism, approaching it as a literary field in its own right. In this sense the collection represents an intriguing extension of and complement to Ruth Solie's essay in The Work of Opera. Whereas Solie uses fictional accounts of the operatic experience to construct a social history of opera in New York's gilded age, Reading Critics Reading suggests ways in which supposedly factual criticism becomes a work of literature. This gesture takes various forms: reexamining the distinction between professional and amateur criticism (Katherine Ellis, Benjamin Walton); problematizing questions of readership, genre, and social and aesthetic status (David Charlton and Sarah Hibberd); and investigating the role and nature of "description" in criticism (Sandy Petrey, Cormac Newark, and Mary Ann Smart).

As Roger Parker points out in his introduction, hindsight often finds critics wanting: the critic out of step with a contemporary or subsequent consensus becomes the historical fall guy (pp. 3-4). The reverse is also true: why, asks Mark Everist, does Berlioz's critical stance on Gluck strike us as less alien than that of his contemporary Castil-Blaze? Although he would later modify his views, the Berlioz of the 1820 s stood as a champion of the classics, convinced of the value of the music of the past and opposed to "tampering with canonic texts" (p. 107). Castil-Blaze, on the other hand, questioned this kind of "textual authority" and sought new directions, new practices. It is Berlioz's attitude, though, that foreshadowed the ideology of the metaphysical "work" that would come to dominate music scholarship and criticism. Despite our increasing distance from that ideology, Everist suggests, there is a lingering familiarity that allows us to comprehend his position. Here Everist introduces a moment of reflexivity that exposes the illusory mastery of the historian and highlights the filters through which that history is constructed. Everist implies that part of this filter lies in our investment in period performance practices, particularly when these are couched in the language of "authenticity." In contrast to what Everist calls Castil-Blaze's "pragmatic historiography" (p. 108), Berlioz's position was a classical idealism at odds with contemporary practices that repeatedly forced him to compromise his principles. He was, in short, a frustrated authenticist, a position that resonates strongly with our own attitudes. And this sense of familiarity with Berlioz's position leads Everist, in an interesting footnote, to introduce a healthy dose of skepticism: "Comparison of Berlioz's and Castil-Blaze's reworkings of Der Freischütz is likely to depend too much on twentiethcentury attitudes to textual authenticity to be of value in understanding how French musical culture consumed this work in 1824 or $1841^{\prime \prime}$ (p. 107). In other words, the filter is apparently so distorting that there is little value in trying 
to get past it. This might be defeatist, but it is a breathtakingly honest acknowledgment of an epistemological, not to say methodological, impasse. ${ }^{9}$

The political dimensions of operatic spectacle have long figured in research on grand opera, and Reading Critics Reading engages closely, and critically, with some of its implications. Like several of the contributors, Mary Ann Smart questions some of the assumptions embodied in Jane Fulcher's influential, though widely contested, The Nation's Image: French Grand Opera as Politics and Politicized Art ${ }^{10}$ (p. 197). Fulcher reads the French reception of La Muette de Portici as prophetic of the strategies that would be adopted by the state to police and manipulate the political import of grand opera. Lavish spectacle, she contends, would shroud potential political signification in a stupefying blanket of material overdetermination and help hold back a tide of seething revolutionary spirit. Smart relates this thesis to the state reaction in France to Donizetti's last opera, Dom Sébastien. While both operas were subject to official scrutiny, the treatment of Dom Sébastien, she suggests, undermines Fulcher's contention: "The opera's most lavish scene, the Act III funeral procession, was deemed 'risky' and cut from the [1849] revival" (p. 198). Smart analyzes the critical discourse surrounding the opera, highlighting the political resonances of the lengthy plot summaries characteristic of reviews at the time. But just what, she asks, does "political" mean in this context? The concerns expressed by the authorities over the funeral scene seem to have had less to do with elaborate political allegory than with its tangible, visual recollection of the recent funeral of the popular Duc d'Orléans. Smart foregrounds the very immediate and sensual interaction between stage spectacle and the stillvivid memories of an emotive, spectacular public event. The risk, in other words, lies in a

\footnotetext{
${ }^{9}$ Everist explores issues of historiography and reception theory in depth in his "Reception Theories, Canonic Discourse, and Musical Value," in Rethinking Music, ed. Nicholas Cook and Mark Everist (Oxford: Oxford University Press, 1999), pp. 378-402.

${ }^{10}$ Jane Fulcher, The Nation's Image: French Grand Opera as Politics and Politicized Art (Cambridge: Cambridge University Press, 1987).
}

highly personal and intense recollection rather than in what Smart calls "grand movements of party politics and statecraft" (p. 211).

This surely brings into focus once again that "fraught" materiality identified by Dellamora and Fischlin. The lavish means at the Opéra's disposal both secured and exceeded the terms of its own mimesis: modes of theatrical representation are challenged here not by widening the semiotic and ontological gulf between theatrical and civic spectacle, but by collapsing it. In this way, a whole new field of (material) contingency opens up, and the meaning of representation is reconfigured, or as Cormac Newark writes of La Juive, "what the audience saw really was a procession with an avowed spectacular purpose" (p. 186). The implications for the historian/theorist are far-reaching, for the now-concealed convergences of sensations and memories are not easily recovered. Acutely aware of this, Smart, like Everist, strikes a note of deep uncertainty, wondering if the "political" implications of these convergences are now beyond our reach, represented as they are by little more than a "slightly hollow anecdote" (p. 212). Thus the historian's reliance on the word, on representation and narrative discourse, is challenged by other channels of meaning, ones that seem to foreground the sensual, the immediate, the pre- and post-discursive.

This tension is the focus of Marian Smith's essay on the critical reception-and construction-of signifying practices in ballet during the July Monarchy. ${ }^{11}$ Tracing the relationship between shifting critical notions of ballet's narrative capacities and the decline of the air parlant and instrumental recitative, Smith theorizes a "feminization" of ballet tied to a loss of voice: the perceived "cognitive and linguistic" dimensions of both dance and music succumbed to a form of abstraction allied to a focus on the body of the increasingly prominent danseuse, so that ballet became "less and less a proper medium for dialogue and discourse" (pp. 235$36)$. This reading hinges on the association between discursivity and the narrative, verbal channels of the communicative economy; it

\footnotetext{
${ }^{11}$ Parker's introduction quite rightly draws attention to the performative dimension of criticism (p. 8).
} 
suggests that powerful social and cultural configurations link language-as opposed to other communicative means - to the very possibility of signification. If materiality-of the body, of spectacle-seems to challenge and disperse meaning, it is because language apparently defines itself as meaningful precisely in its capacity to surmount the material. Opera threatens to complicate the picture further. When Smith writes of a loss of voice, she means voice as a metaphor for communicative agency. Voice might operate in similarly metaphorical terms in opera, but now there is also the question of its very tangible presence as the primary medium through which opera is realized. So in addition to understanding the role of "envoicing" in opera, we must grapple with its acoustical materialization.

\section{Performing on Command}

The tension between metaphorical and acoustically "real" voices has been an important focus of Carolyn Abbate's work. It formed the background of her exploration of musical narrativity in Unsung Voices and problematized questions of agency and gender in "Opera; or, the Envoicing of Women."12 This tension resurfaces in Abbate's latest book, but now reoriented so that performance becomes less a means than an end. In Search of Opera is in part a phenomenology of operatic performance, one that seeks to critique the legacy of the operatic "work" as inherited from nineteenth-century aesthetic ideology. Citing Lydia Goehr's genealogy of the "work-concept," Abbate contends that "Western intellectual culture" has traditionally resisted the embodiment/materialization of the musical work in favor of its untouchable, uncompromised form as imaginary object. $^{13}$ In this context, she argues, the fleet-

\footnotetext{
${ }^{12}$ Carolyn Abbate, Unsung Voices: Opera and Musical Narrative in the Nineteenth Century (Princeton: Princeton University Press, 1991); Abbate, "Opera; or the Envoicing of Women," in Musicology and Difference: Gender and Sexuality in Music Scholarship, ed. Ruth A. Solie (Berkeley and Los Angeles: University of California Press, 1993), pp. $225-58$.

${ }^{13}$ Lydia Goehr, The Imaginary Museum of Musical Works: An Essay in the Philosophy of Music (Oxford: Clarendon Press, 1992).
}

ing, elusive yet material qualities of performance are devalued, even disparaged, as threatening both the permanence and disembodied idealism of the imaginary work. In Search of Opera sets out to redress this imbalance not by examining any specific performance, recording or mise-en-scène, but by assembling a web of tropes of performance drawn from operatic works themselves, from visual images, verse, fairy tales, philosophy, even a tomb.

Abbate anticipates the criticism that such a failure to reckon with performance as event, as realization, might represent, to use her own words, a "fatal defect" (p. xii). It is hardly that, although her approach does occasionally back her into a corner of her own making. A chapter on Pelléas et Mélisande, for example, explores impossible sounds and what Abbate calls the "double work" brought about by performance. In the love scene in act IV, she argues, Pelléas is so intoxicated by Mélisande's voice that he no longer hears her words, only the sheer sensual beauty of her voice. But, writes Abbate, what "beckons the listener as an object of desire" is not Mélisande's voice but Pelléas's rhapsodic, arialike response "on dirait que ta voix a passé sur la mer au printemps," a passage from an early draft that was later inserted into the scene like a self-contained musical object. Musical performance reverses the structure of desire, and the gender politics, evident from reading the poetic text: "Words make the woman into the singing bird, but their sung performance demonstrates that male vocality can rival any woman's for embodiment and intoxication, as a voice whose own words can easily go unheard" (p. 177). And of course the gesture of reversing the musical investment has the effect of concealment, leaving Mélisande's supposedly ravishing voice as a phantom.

Lurking behind this is the familiar musicological habit of reading music as subversive of poetic text, as though tracing the order of the creative process to say "first poetry implies this, but when opera adds music we get this." Familiar, too, is Abbate's textually based invocation of the arialike independence and lyricism of Pelléas's rhapsody. These formal features may shape "sung performance"; they may indeed only be realized by it, but they are still grounded in text. It is only with the "embodi- 
ment and intoxication" of Pelléas's voice that we get beyond text to the exclusive domain of performance. Yet Abbate's desire to honor what she calls "physical or ephemeral phenomena" (p. 52) means opening the reading up to the contingencies of performance, and the terms might become less stable than Abbate's neat reversal would imply. Might the performance of a given pair of voices-say, an uninteresting baritone and an intoxicating soprano (p. 183)not actually confirm rather than subvert the poetic text? This is where Abbate seems to hedge her bets, simultaneously debunking and investing in the imaginary work.

On the whole, though, Abbate theorizes performance with a subtlety and nuance that allows for its reversals and contradictions. In Search of Opera presents performance as a complex network of practices and discourses incorporating "composer, inscription, performer, interpretation, realization, and reproduction" (p. xiii). These relationships, Abbate stresses, are "full of antagonism" and may not function in the directions we might assume (p. xiii). Abbate wonders, for example, about the possibility of an "uncanny" reversal in which performers are seen not as the animators of dead works, but as inanimate material brought to life in ventriloquist fashion by the work (p. xiv). In this way the moment of realization is both contextualized and problematized, and some potentially rich territory opens up for the theorization of performance. Here the absence of "real" performances is no weakness. Abbate investigates the textual sources and traces of this performance network with such virtuosity and insight that the book can be seen to justify its own reach, leaving to another day the kind of research that might investigate performance in more specific times and places (with its attendant risk of sliding into empiricism and positivism).

Abbate's reading of The Magic Flute exemplifies the richness of the cultural nexus she is able to summon. Her argument revolves around the figure of a haunted Enlightenment, here embodied in the simultaneous fascination with and horror of mechanical repetition. For Abbate, The Magic Flute, with its enchanted bells, clockwork voices, and music-box songs, registers a turning point at which mechanized music, still captivating, begins to reveal a dark side suffused with images of automata and dehumanizing machines. And caught in this tension is the very idea of performance as mechanistic animation. Abbate is well aware that such shadows are a familiar figure in Enlightenment critique; what she seeks, rather, is a "nocturnal" counternarrative accompanying Enlightenment ideologies, a shadow, in other words, that is not merely an "inversion" made possible by "late-twentieth-century historical revisionism" but a kind of double revealed in the literary and visual discourses that resonate from the opera and form its genealogy (pp. 104-05).

Doubles haunt the book throughout: performance may resonate with "aftershocks" and defy its own mortality, but it is also "always in flight," "fad[ing] away" (p. 239); music can exercise "violent force" and "lull" in a floating euphoria (p. 53); opera can conjure a timeless essence and restlessly seek realization (p. 144). But perhaps nothing is so haunted in this book as the bodies of performers, who find themselves variously decapitated, dismembered, possessed, and mortified. Nor is death any refuge, for performance reanimates the corpse, adding a new twist to the phrase "performing on command," and suggesting that the operatic zombie identified by Dolar and Žižek operates on a number of levels. Abbate's work has always been characterized by a willingness to challenge orthodoxies and scholarly fashion, and the angst, even terror, that this reading of performance generates represents a call to rethink, or at least supplement, prevailing attitudes. While far from dismissive of rhapsodies to the pleasurable "presence and excess" of operatic performance or "celebrati[on]" of "operatic works as an envoicing of women" (a reference that would include her own work), Abbate wonders if "less euphoric conclusions" might be drawn about performance (p. 9). Perhaps the most impressive aspect of this book is the rigor and imagination with which this disquiet is explored. In Abbate's hands the figure of the decapitated head of Orpheus, still singing, elides the distinction between (living) voice and (dead) instrument, generating a foundational tension in opera between embodied and disembodied sound, enchanting persuasion and overwhelming force, instruments and instrumentalization. 
And the menacing shadow of the machine is never far away, its implications explored in an extraordinary closing chapter centered on tropes-Rousseau's tomb, Ravel's fraught mechanism-that straddle images of life and death. For Abbate, finally, the fate of the performer's body, its proximity to the machine, maps onto the traumatic character of modern subjectivity, but also marks its limits, gesturing to a loss and a horror that threaten to collapse into impossible domains.

More problematic is the strangely peripheral role assigned to the body of the listener. Its imagined position in a live performance is presented as formative in the experience of recorded sound (p. 210), and in a discussion of Parsifal it is summoned rather abruptly to account for a textual twist: a break in a harmonic pattern signals for Abbate a shift from the world of the stage and the plot to "one constructed by music," and this musical world foregrounds the "inner secrets of a body," not the body of a character or performer but of the listener (p. 141). Otherwise, though, the listener's body tends to feature only tacitly, figuring, for example, as a merely implied object/recipient in Abbate's accounts of music's violence and power. Part of the problem here again is Abbate's stated aim of challenging what she calls the "text-oriented stance toward the performed arts" and gesturing toward an investment in the material and the embodied. She is quite right, I think, to identify the failure to engage with performance and performers as a critical shortcoming in operatic scholarship, but I would suggest that the embodied experience of listening has been equally overlooked until very recently. Despite intermittent references, listening tends to get squeezed out of In Search of Opera at decisive moments. Abbate, for example, targets feminist approaches to the classical repertoire (with Susan McClary as the usual suspect) for their failure to break with text-based scholarship: "The text, the authority of a male composer, and the strangleholds of objectification and representation, are ultimate objects of celebration, and in a peculiar sense the music-the realization of that text, and those responsible for it-has begun to vanish" (p. 51). Does this neglect of performance, she asks, not conflict with a feminist concern about the cultural tendency to devalue "physical or ephemeral phenomena," to treat "immediacy and pleasure" with suspicion (p. 52)? Citing Suzanne Cusick, she wonders if "the music itself," a term that sums up the imaginary work and its disembodied music, is "the ultimate feminist issue" (p. 51).

To the extent that feminist approaches to music can and do overlook performance, Abbate's complaint is not unreasonable, but surely the embodied experience of listening has something to do with immediacy and pleasure as well. In this respect feminist musicologies, including McClary's, have done much to remind us of the body, the ephemeral, and the material. Nor are Cusick's concerns about "the music itself" in any way confined to the neglect of performance: "No 'extra-musical' concern-such as a focus on the bodily acts that cause music to sound, or on bodily responses to sound other than those of the ear and mind, or on the interplay of aestheticized sound-patterns with the social, physical, and linguistic practices that surround and accompany performance and reception-is included in the definition."14

The problem, for Cusick, is broader than Abbate implies, and it suggests that the issues generated by the question of performance are thoroughly bound up with issues of reception. At stake here is the social situatedness of performance, its definition as a practice undertaken not only by but for someone. And is this listening, spectating other not, in Bakhtinian terms, "anticipated" in the performance? This might suggest that Abbate's performance "network" should include reception, that the embodied, material acts of performance are inseparable from the embodied, material acts of reception. It might imply, too, that listening and spectatorship are forms of performance in their own right, acts of engagement that can succeed or fail, enrapture or alienate. Abbate's phenomenology of performance seems inclined in another direction, marginalizing the listener

${ }^{14}$ "Gender, Musicology, and Feminism," in Rethinking Music, p. 492. Later Cusick adds: "Its definition by opposition to bodily performances, bodily responses, and the social and linguistic constructs that surround performance and reception imply that it is a music that transcends the always unpredictable, always subjective vagaries of the body" (ibid.). 
and privileging - even as it problematizes-the relationship of performance to text and work.

\section{In Search of Mystery}

Performance, though, is only one half of the dual focus of In Search of Opera. Abbate seeks to understand the paradoxical coexistence in opera of the material and fleeting with the transcendent and metaphysical. This coexistence is brought vividly to the fore in Abbate's reading of the "phantom" of Mélisande's voice. What she proposes is that the real, acoustically present music of Pelléas might live up to its ideal, becoming in actuality what words imagined it to be. That is, the musical phantom conjured by language becomes a phantom realized in music: Debussy grounds the ideal music in reality but maintains the mystery of the phantom. Abbate's reading reflects intriguingly on the relationship between representation and performance, directly challenging the Symbolist musical ideal with musical practice. Yet this substitution of an imaginary for a real music does nothing to challenge-indeed affirmsthe Symbolist investment in a mystery founded on musical ineffability; the symbol may give way to representation, but the ideology remains intact, and this ideology provokes important questions. Does Symbolist ineffability not represent an elision of mystery with sheer mystification, and do its doctrines not sustain themselves on a rampant aestheticism all too eager to flee the world?

As she does throughout In Search of Opera, Abbate cites the musical writings of French philosopher Vladimir Jankélévitch and seeks in them a theoretical model of music that productively mines Symbolist conceptions of its ineffability without silencing its capacity to speak..$^{15}$ The trouble with this ineffability, though, is its capacity to serve as metaphysical refuge from or antidote to the world. Concluding an article on Debussy and Fauré, Jankélévitch uses a discussion of Fauré's Requiem as a springboard to appeal to music's celestial climes: "Divine mu-

\footnotetext{
${ }^{15}$ Abbate has recently translated one of Jankélévitch's major texts on music. See Music and the Ineffable (Princeton: Princeton University Press, 2003).
}

sic, deliver us also, we who are not dead like the dead, but dead like the living, that is to say, ugly, nauseating, and cadaverous, deliver us from the depths; do not refuse your mystic washing to our departed souls; and may your melodious angels forever chase away from us the anxious Valkyries of wrath."16

The date of the article, 1945, is significant: in this context the desire for solace and the sense of disgust is more than understandable, and the reference to "Valkyries of wrath" takes on a political dimension. But there is something all too familiar about this. As so often in the wake of the nineteenth century, it is music that occupies this hallowed sphere of redemption. This is not to say that music does not offer solace-is this not one reason why we invest in it?- but this would not distinguish it from language or the visual. And what about the other capacity of music, the capacity to speak all too vividly about worldly things, to attach itself effortlessly to words and images? We might theorize this readiness to attach as a sign of music's semantic indeterminacy, but it might also be indicative, as Lawrence Kramer has argued, of the broader "ascriptive" economies by which all meaning is formed. ${ }^{17}$ That is, the apparently parasitic process by which music borrows concrete meaning, far from peculiar, is actually symptomatic of the formation of meaning generally. And surely the performative effect of music's almost promiscuous interaction with other discursive forms is to embed it within a socially determined, intersubjective, and thoroughly worldly experience.

There is of course a danger that this more worldly account of musical meaning oversimplifies or renders transparent the processes by which music engages with our experience, the processes by which the musical subject is formed and deformed. Abbate is quite right to worry about interpretations of music predicated on "breathtakingly straightforward reflections"

16"Pelléas and Pénélope," trans. Arnold I. Davidson and Nancy R. Knezevic, Critical Inquiry 26 (2000), 590. Originally published in Revue historique et littéraire du Languedoc (1945), 123-30.

${ }^{17}$ See Musical Meaning: Toward a Critical History (Berkeley and Los Angeles: University of California Press, 2002), p. 166. 
of a range of ideologies, genres, and strategies. Subtlety and sophistication have not always been the hallmarks of recent critical and interdisciplinary engagements with music, opera included. What troubles Abbate, though, is not the validity of these engagements but what she calls the "sharp objects in the writing," a failure to find a language for music that is sympathetic and idiomatic (p. ix). The result is that the very object of inquiry is lost, subjected, Abbate implies, to an apparatus that is obtrusive and obvious.

What, then, does Abbate propose? For her the "greatest exception" to the shortcomings of music scholarship is the work of Jankélévitch, with its sensitivity to what he calls an "unreal chimera" (p. ix). Jankélévitch molds his language to the ineffable qualities of music-" no pins, no jagged edges"-something that much scholarship has failed to do (pp. viii-ix). But this brings us back to the Symbolist desire, predicated on a polarization of music and language, that language become like music. This polarity might be questioned not only by asserting music's engagement with the world and with discourse, but from the opposite perspective too: we can acknowledge music's capacity to suggest the intangible, but again, why would this distinguish it from other media or communicative forms? When Abbate contends, following Jankélévitch, that music "draw[s] the mind on to a vanishing point that can never be reached," or likens musical meaning to a "hall of sonorous mirrors" (p. 145), she could be articulating poststructuralist or Lacanian views of language. The connection with Symbolist thought is no accident: the prominence of Mallarmé and other canonic Symbolist writers in the work of Derrida and Lacan is a reminder of the importance of the early modernist problematization of language to the French postwar intellectual tradition. That the Derridean deferral of meaning or the Lacanian chain of signifiers question the capacity of language to signify with the kind of certainty traditionally ascribed to it is by now familiar-some will say all too familiar-to musicologists. I would argue, however, that musicology has only begun to engage with the potential of this theoretical tradition to redefine and refine music discourse, and particularly to offer models from which musicology might develop precisely the kind of subtle theoretical apparatus that Abbate seeks. The modest progress to date is hardly surprising: musicology has only recently, and reluctantly, emerged from self-imposed isolation. The fact that the by-now worn out term "New Musicology" refuses to go away suggests that it has not quite lost its novelty value; more time is needed to flex methodological and critical muscles, to absorb and respond to a rich interdisciplinary network of ideas, to develop critical strategies more idiomatic to the field and less inclined to wholesale borrowing.

Abbate is critical of what she calls "the divining rod of post-structuralist knowledge," but the kind of certainty this suggests is precisely what poststructuralism questions. What it does, in fact, is to offer a means of bridging the gap defined by Abbate, not by forcing discourse to follow the mystical lead of an ideal music in flight from the world, but by drawing both music and language into a performative and interdisciplinary economy that is skeptically aware of its own limits, but always engaged with grounded experience. As Alastair Williams reminds us, Derrida in fact addresses the problem of groundedness, perhaps countering a tendency to read his own work as disengaged from social and political accountability. The text, Derrida writes,

does not suspend reference-to history, to the world, to reality, to being, and especially not to the other, since to say of history, of the world, of reality, that they always appear in an experience, hence in a movement of interpretation which contextualizes them according to a network of differences and hence of referral to the other, is surely to recall that alterity (difference) is irreducible. Différance is reference and vice versa. ${ }^{18}$

And why should this not apply to the musical text (understood here not as a "work," but in Barthes's sense of a network that "is experienced only in an activity of production"|? 19 Is

\footnotetext{
${ }^{18}$ Jacques Derrida, Limited Inc, trans. Samuel Weber and Jeffrey Mehlman (Evanston, Ill.: Northwestern University Press, 1989|, p. 137. Cited in Alastair Williams, Reconstructing Musicology (Aldershot: Ashgate, 2001), p. 41.

${ }^{19}$ Roland Barthes, "From Work to Text," in Image, Music, Text, trans. Stephen Heath (New York: Hill and Wang, 1977), p. 157.
} 
music's apparently endless play of signification not equally mediated by experience, the socially and culturally situated experience of the participants in its productive network? There is no "divining rod" here: meaning remains problematic, but music loses its privileged access to the ineffable.

\section{Thinking the Sensual}

Psychoanalytic theories of voice also often turn on the problem of musical meaning, but here the emphasis is less on the idea of exceeding than of preceding signification. One of the definitions of the work of opera offered by Dellamora and Fischlin is the "public shaping of voice" (p. 6), reminding us that voice is not merely a given that is then utilized by opera; rather, opera is a staging of the boundaries of voice. In this context the editors cite Kaja Silverman's psychoanalytic reading of voice as "the site of perhaps the most radical of all subjective divisions-the division between meaning and materiality." 20 At stake here is the very emergence of the subject, constituted in the doubling of voice as both imaginary selfpresence and as the Other that disturbs that self-presence by introducing into its core something alien, something "outside." It is with the introduction of this difference and absence that meaning emerges as such. Lacanian theory interprets voice as revisiting and recrossing this division. Normatively charged with meaning, but capable of slipping into a pure materiality beyond meaning, the operatic voice would stage Silverman's subjective division. ${ }^{21}$

\footnotetext{
${ }^{20}$ Kaja Silverman, The Acoustic Mirror: The Female Voice in Psychoanalysis and Cinema (Bloomington: Indiana University Press, 1988), p. 44. Cited in The Work of Opera, p. 6 .

${ }^{21}$ Michel Poizat, for example, draws a line between the primal "cry," a nonsignifying sonorous realization of the infant's presymbolic, presubjective wholeness, and the signifying utterances that postdate its separation from the mother. Whereas the former centers on materiality and plenitude, the latter is generated by lack (of the mother, of objects). There are exceptional moments in opera, Poizat suggests, that articulate this cry, moments when a presubjective jouissance breaks through signification and foregrounds the material dimension of voice. Gary Tomlinson detects in this dualism the Kantian transcendental subject limited in its knowledge to the appearance of things (the phenomena) and barred from access to the
}

Judith Butler, among others, has questioned this kind of division by emphasizing the always material dimension of meaning, of discursive networks.22 This goes beyond merely acknowledging the materiality of the signifierin this case the physical, embodied production and perception of voice as acoustic phenomenon-to assert the material operations of the signifying network in all its social, communicative, libidinal, and psychical spheres. And for Butler any consideration of the relationship between signification and the material must also consider the extent to which the two are intertwined from the very beginning: "To posit by way of language a materiality outside of language is still to posit that materiality, and the materiality so posited will retain that positing as its constitutive condition" (p. 30). In other words, we cannot speak of an absolute "outside" to language without performing that outside. We need to consider how such an exclusion has the effect of forming that which is excluded, how this excluded outside might return in unexpected ways (p. 31), and this might offer a fruitful means of (re)considering the "fraught" materiality of opera.

These are some of the questions addressed by Lacanian theorist Mladen Dolar in Opera's Second Death. Dolar presents opera as powerful terrain for philosophical discourse, a gesture that rests, like The Work of Opera, on a performative premise: "Music, in opera, stands in a self-reflective relationship-it performs its own representation, it stages its own power and its effects" (p. 10). What it stages until the late eighteenth century, he argues, is the mobilization of music to elicit the mercy of the Other, to awaken love in the master, the god, the lover (p. 11). But this "logic of mercy" begins to unravel, confronted with the Enlightenment assertion of the autonomous subject.

things in themselves (the noumena). Does Poizat's "cry" not represent, as Tomlinson argues, a classic noumenal object? Does the psychoanalytically based assertion of a jouissance prior to meaning hinge on the survival of the noumenon? (Gary Tomlinson, Metaphysical Song: An Essay on Opera [Princeton: Princeton University Press, 1999], p. 86). Michel Poizat, The Angel's Cry: Beyond the Pleasure Principle in Opera, trans. Arthur Denner (Ithaca, N.Y.: Cornell University Press, 1992).

${ }^{22} J u d i t h$ Butler, Bodies that Matter: On the Discursive Limits of "Sex" (New York: Routledge, 1993), p. 30. 
Nowhere, Dolar suggests, is this more clearly articulated than in the late operas of Mozart. But he offers no undialectical celebration of the emergence of autonomy. Drawing heavily on Ivan Nagel's Autonomy and Mercy, Dolar finds in Mozart's operas an often contradictory intertwinement of the new subjectivity with the old order it seeks to replace. This paradoxical combination-Nagel writes, for example, that "bondage to fate can, absurdly enough, be broken only by the favor of fate" - plays a central role in Dolar's subtle critique of Enlightenment. ${ }^{23}$ Like Abbate, he detects within the new autonomy the lurking figure of the automaton, here embodied in the machinelike precision with which love, far from spontaneous, appears on cue in the social experiment that forms the plot of Cosi fan tutte (pp. 61-65). In this sense, Cosi is both progressive and regressive: progressive in that it questions the naïveté of the new bourgeois claim for the morality and truth of natural feeling; regressive, in that a gaze, the "absent gaze of the master," presides over the experiment, enjoying the spectacle in the manner of the absolute monarch (pp. 72-73). In the figure of Don Juan, Dolar detects a fundamentally ambiguous combination of the "old order," the order of the master who demands obedience and compliance, and the new liberté of the bourgeois subject free to pursue its own pleasures. But Dolar further develops this ambiguity into a dialectic: the Don is the bourgeois subject who "had the courage to go to the limit" (p. 49); in him the liberty of the autonomous subject is taken to its extreme and reveals its other face, the "destructive" pursuit of his own desire "without the mask of equality and fraternity" (pp. 49-50).

Drawing on Kierkegaard, Dolar wonders how music might participate in this staging of subjectivity. Kierkegaard presents music as the quintessentially Christian art, not because it

\footnotetext{
${ }^{23}$ Ivan Nagel, Autonomy and Mercy: Reflections on Mozart's Operas, trans. Marion Faber and Ivan Nagel (Cambridge, Mass.: Harvard University Press, 1991), p. 26. It is only in a footnote that we find an acknowledgment of what Dolar calls "the main source of inspiration for this study" (p. 93, n. 30). In his reading of Mozart's operas, Žižek similarly acknowledges a debt to Nagel's "path-breaking study." See Tarrying with the Negative (Durham: Duke University Press, 1993), p. 271, n. 1.
}

serves Christianity, but because Christianity has had to exclude its sensual power (p. 52). Christianity, then, establishes music's power by negation, by exclusion. Dolar mobilizes this logic to deconstruct the appeal for mercy that he has presented as the founding gesture of opera. If Kierkegaard invested in the "demonic sensuality" (p. 57) of opera-embodied in the figure of Don Juan-only so that he could ultimately reinforce the triumph of religion and morality over it, Dolar sees this sensuality as a sign of opera's fundamental ambiguity. Is it possible, he asks, that music's appeal to the Other is at the same time a seduction: "The highest force of love and mercy coincides with its excluded opposite, with the lowest demonic force of sensuality, with radical evil" (p. 57). He wonders, too, if the relationship between opera and philosophy-a central theme of his contribution-might be understood in the same way: philosophy must exclude the "sensual fascination" of opera in order to "constitute its concepts at all," but in doing so it actually creates the space from which opera emerges (p. 58).

Dolar brilliantly probes the dialectical consequences of Kierkegaard's notion of sensuality, showing how its relationship to spirit /defined as both suprasensual unworldliness and the stony, permanent, "double of life") exposes its own double quality, at once elusive intangibility and stagnant, mortified permanence (pp. 55-56). He goes on to show that in Kierkegaard's reading of Don Giovanni, music and the figure of Don Juan coincide as the embodiment of a sensuality that eludes language. For Kierkegaard, "music always expresses the immediate in its immediacy. ... In language there is reflection and therefore language cannot express the immediate" (p. 52). As unrepresentable sensuality, music finds its most authentic space in Don Giovanni, but this impossible musical object can only be staged by falsifying it, shrouding it in representational means. What Dolar does not do is critique Kierkegaard's alignment of music and sensuality, despite the fact that his recognition of constitutive exclusions would seem to point in that direction. In other words, is it possible that the very gesture of excluding musical immediacy and sensuality from representation defines music as immediate and sensual in the first place? 
As a means of reconfiguring the noumenal character of this alignment of music and sensuality we might turn to Dolar's fellow Lacanian theorist Slavoj Žižek. For Žižek, the noumenon does not precede or form a limit to our field of knowledge; rather, our experience of "reality" Lacan's Symbolic order-depends on the exclusion of a "mythical object" that would bring about total satisfaction if only we could attain it. ${ }^{24}$ The limit creates the impression that beyond it is the unattainable Ding-an-sich. This " $\mathrm{x}$," this substantial entity that is barred to us and that we only access via its surplus (the phenomenon), comes to function retroactively as the absence around which our symbolic experience revolves. ${ }^{25}$ The surplus, in other words, precedes and generates the substance, or, to return to Kierkegaard's terms, the libretto and mise-en-scène las surplus representation to music's immediacy) "generate" the substance of musical immediacy precisely by positioning it as inaccessible/unrepresentable.

\section{Traversing THE FANTASY}

Critical to Žižek's logic is the late-Lacanian emphasis on the Real, a term that designates this remainder/surplus, this necessary limit and failure of symbolization. Žižek's overall project can be understood to center on theorizing the diverse political, social, and cultural manifestations of the relationship of the Real and the Symbolic. Opera-particularly Wagnerian opera-features repeatedly in Žižek's cultural landscape, and his contribution to Opera's Second Death incorporates and further develops parts of his existing body of work. Unlike Dolar, who often engages quite closely with Mozart's operas (music included), Žižek tends to take a broader view, combining an incisive ideology critique of plot and character with the construction of a transdisciplinary network of media and ideas. If the only passing consideration of music is a shortcoming-many of Žižek's insights could be applied to the libretti alone

\footnotetext{
${ }^{24}$ Tarrying with the Negative, pp. 36-37.

25 Žižek argues that the noumenon "is retroactively produced by the very process of symbolization" (Tarrying with the Negative, p. 37).
}

without disturbing their fundamental premisethe philosophical payoff is so rewarding that it seems churlish to point out what is missing. That payoff takes the form of the identification of a fundamental fantasy at the heart of Wagner's project, a fantasy of full satisfaction.

Zižek stresses that the Real must be understood in all its negativity: it is the void against which and around which our "reality" is structured. To experience the Real amounts to a fantasmatic gesture: it magically resolves the very deadlock that makes reality possible and that therefore cannot be assimilated into our experience. We cannot "experience" the Real since it is the negative foundation of what we know as experience in the first place. Instead, we invest in objects that take the place of this void, objects that simultaneously "give body" to the void and sustain its empty space (as we saw, there is no substance prior to the surplus). The Real is the register of jouissance, the excessive enjoyment that must be excluded from the Symbolic in order to sustain the subject as such. To seek out jouissance, to approach the object of desire too closely, is to become aware of the fundamental ambiguity of the object, that the pleasure it generates will quickly give way to disgust. That is, the object is not pleasurable per se, but excessive, and that excess can only remain pleasurable as long as we maintain an appropriate distance on the Möbius strip leading to disgust, a distance that sustains subjectivity. Žižek stresses that disgust is not "the secondary effect of repression," a "turning away" from objects that are "prohibited by the symbolic norms" (p. 145). Rather, prohibition is itself the means by which the continuity of pleasure and disgust (recall Kramer's argument) is concealed and given an external cause: "Prohibition transposes this inherent self-blockade into the effect of the external obstacle; were it not for the prohibition that prevents access to it, the object would give full satisfaction" (p. 145). It is precisely this fantasy of full satisfaction that Wagner reinforces, above all in the socalled Liebestod of Tristan und Isolde.

Žižek begins with the premise that the Liebestod does not present Isolde's death, but rather-and here he takes his cue from Raymond Ponelle's famous staging-Tristan's fantasy projection of his own actual death. 
Ponelle's staging articulates the "repressed truth" (p. 221) of this scene, exposing its roots in a "male fantasy" staged, like all fantasies, for a "third gaze," the gaze of the big Other imagined to witness the act. Isolde begins by addressing the Other directly, but gradually withdraws from "intersubjective" relations to "a self-immersion that disavows the Other" (p. 131). Here we enter a domain of "self-obliteration" in which the fantasizing Tristan transgresses the limits of the Symbolic order altogether, conflating the surplus fantasy object of orgasm (the little death) with the "big" death, the impossible jouissance of the Real (p. 131). In other words, Tristan passes from an appeal to the Symbolic (the big Other) to a disavowal of its existence. And how is this ultimate transgressive experience presented? It is pure ecstasy, unclouded by any trace of the contradictory, impossible character of jouissance. It is as though we could exceed the parameters that make pleasure possible and meaningful while simultaneously experiencing pleasure.

The problem, Žižek argues, is not the idea of approaching the Real as such, but how that approach is undertaken. The goal of Lacanian psychoanalysis is to "traverse the fantasy," to reavow responsibility as a subject for positing the fantasy object. It is not the Other that has taken away this object that I demand for myself. By traversing the fantasy I acknowledge that there is lack in the Other, too, that the Other does not exist as it did in my fantasy. It is thus by realigning my Symbolic experience that I approach the Real, and this, for Zižek, is what Tristan (and much of Wagner) obscures when it celebrates "the lethal, transgressive experience of going beyond the (symbolic) limit" (p. 176). In the Liebestod, the Other is merely disavowed in a total immersion that reaffirms and takes to the extreme the contours of the fantasy. What Žižek seeks instead is a "heroic acceptance of the nonexistence of the Other," something he detects, for example, in Primo Levi's accounts of Auschwitz (pp. 222-23). His proposed musical counterpart to this acceptance, however, is, to say the least, disappointing.

In a move reminiscent of Adorno, Žižek proposes that Webern's renunciation of the "ideal listener," the refusal of his music to imagine an audience for itself, constitutes just such an acceptance. Thus the transformation brought about by "traversing the fantasy" turns out to be nothing more than a celebration of high modernism. And where does this leave opera, with its inherent, intense awareness of the spectator? Since opera is apparently dead, the question hardly seems relevant. But Zižek's focus is on composition; what if we consider interpretation? If Ponelle can stage Tristan with such revealing insight-and Žižek refers to it as "occup[ying] the exceptional place of the repressed truth of Wagner's Tristan itself" (p. 221)—is there a place for the theorist of opera to traverse the fantasy? In a chapter entitled "Transgression? No, Thanks!" Žižek problematizes theory's investment in subversive ecstasy: "If the fate of subjectivity in late capitalism has anything to teach us, it is how such ecstatic transgressive gestures (from Bataille to Foucault and, perhaps, including Lacan himself in his fascination with the figure of Antigone) are in advance 'part of the game,' not only tolerated but even directly elicited by the capitalist system" (pp. 133-34). The implications of this argument are far-reaching, for it suggests that we need to reconsider the traditional fascination with jouissance. Is it possible that the Lacanian Real might be rethought so that it embraces not only the unthinkable of sexuality, but of capital?

Opera's Second Death never elaborates on the possibility, but this is something that Žižek has explored at length elsewhere. ${ }^{26}$ Postmodern political struggles, he argues, have done much to "repoliticize" domains previously thought of as "apolitical," but they have held on to a notion of capitalism as apolitical "because the very notion and form of the 'political' within which it operates is grounded in the 'depoliticization' of the economy." But what, he asks, if this gap, this exclusion, is the very key to understanding what operates as the Real today? Is it possible that the "class-and-commodity structure of capitalism is not just a

\footnotetext{
${ }^{26}$ See in particular "'I Hear You with My Eyes'; or, The Invisible Master," in Gaze and Voice as Love Objects, ed. Renata Salecl and Slavoj Žižek (Durham: Duke University Press, 1996), pp. 90-126; and Žižek's intro. to Mapping Ideology (London: Verso, 1994).
} 
phenomenon limited to the particular 'domain' of economy, but the structuring principle that overdetermines the social totality, from politics to art and religion" ?27 That opera is historically deeply intertwined with the politics of class and economy has hardly gone unnoticed, but taking Žižek up on this suggestion would represent a dramatic shift in focus from the recent concentration on issues of gender and sexuality; it might open new theoretical doors, expanding on some of the issues explored in The Work of Opera, particularly in the editors' introduction and in Solie's essay.

But how would we take Žižek up on this suggestion? Where, for example, does this leave the more orthodox Lacanian apparatus and Žižek's own thorough mobilization of its focus on sexuality? Is Judith Butler not quite justified in claiming that Žižek's theories assign sexual difference a "'quasi-transcendental' status"? In Lacanian terms, sexual difference has no content as such; it is traumatic and unnameable in relation to the Symbolic order, shaping it as negative space. Yet now we find that this traumatic emptiness, this unknowable negativity, might be the location of capital or class struggle-and with the latter term Žižek seems to turn the tide back to an earlier era of Marxist criticism. The suspicion then arises that the supposedly unnameable realm of the Real might allow itself to be named. For Butler, the problem here is the Lacanians' insistence on the "purely formal" character of the Real. Surely, she contends, this form/content distinction is not tenable, dependent as it is on "a process of abstraction that is never fully free from the remainder of the content it refuses." 28

Here I am reminded of the constitutive exclusions explored by Dolar, and we might ask, following Dolar, how the exclusion returns. Is it possible that the neglected political dimension of class and economy comes back, not merely as a formal "structuring principle" (as Žižek would have it), but as a remainder generated by its very exclusion? Žižek would no doubt argue (as he does contra Butler) that my

\footnotetext{
${ }^{27}$ Judith Butler, Ernesto Laclau, and Slavoj Žižek, Contingency, Hegemony, Universality: Contemporary Dialogues on the Left (London: Verso, 2000), pp. 98, 96.

${ }^{28}$ Ibid., pp. 143, 144, 144-45.
}

argument conflates symbolic "difference/opposition" with the "impossible-real" character of "antagonism." So, for example, "the difference ... which separates woman from man is 'antagonistic' in so far as it simultaneously 'bars' the woman from within, preventing her from achieving full self-identity (in contrast to a pure differential relationship, where the opposition to man defines woman's identity)." For Butler, this raises the question of who has access to claims made on this supposedly presymbolic, a priori level. She wonders, too, if Žižek's alliance of capital with the Real might challenge the latter's "unspeakable" character and demonstrate that the "absences that structure discourse ... are defined in relation to the discourse itself, and . . . are not derivable in every instance from an ahistorical 'bar' that gives us every historicized field." 29

In what sense, for example, has Adorno's "bourgeois opera" become "corporate opera," one high-end product in the new "globalized" economy? Again the Royal Opera House is instructive. In 1993 its marketing director described efforts to work in partnership with Virgin Atlantic Airways: "Interval suppers, red carpets. ... We need to sell the whole experience rather than just La Bohème. . . . We are trying to learn the way to have a brand image like Virgin - to say the $\mathrm{ROH}$ experience is more than just the performance." 30 This ambition has been fully realized, particularly since the completion of the $\mathrm{ROH}$ renovation with its Floral Hall, an adjacent glass atrium available for corporate receptions and meals during intermissions. ${ }^{31}$ Britain's Daily Telegraph reported recently, for example, on a special offer presented to charities to encourage sales for a badly undersold production of Henze's Boulevard Soli-

\footnotetext{
${ }^{29}$ Ibid., pp. 214-15; 275-77.

${ }^{30}$ Times (12 July 1993), cited in David T. Evans, Phantasmagoria: A Sociology of Opera (Aldershot: Ashgate, 1999), p. 127. Virgin's tongue-in-cheek "branding" of its premium business-oriented in-flight service as "Upper Class" offers an interesting take on the genealogy of the new corporate aristocracy.

${ }^{31}$ In a reference to "lager louts," a British term for hooligans, Rodney Milnes once referred to the $\mathrm{ROH}^{\prime}$ s intended audience as uninformed "champagne louts," thereby opposing a corporate elite with a taste elite. Rodney Milnes, "40 Years On," Opera (March 1989), 269. Cited in Evans, Phantasmagoria, p. 139.
} 
tude: "The best seats in the house' with a glass of champagne and six oysters at the ROH's main bar thrown in for just $£ 60 .{ }^{\prime \prime 32}$ Brand image indeed. The point, of course, is that the Royal Opera House is not so exceptional, that the widespread collapse of government funding for the arts has forced opera to embrace a globalized corporate culture as an evermore vital successor to national support and to the old order of the bourgeoisie. We might then ask how this "cultural capital," to use Pierre Bourdieu's phrase, impacts on opera at every level, shaping not only repertoires and casting, but creative decisions. ${ }^{33}$ And if we as theorists wish to situate the formation of meaning in the context of contemporary reception-if we wish, in other words, at least to attempt to engage in the sort of reflexive process that McClary imagines, acknowledging our own experience of opera-then we need to consider more fully the ideology of this new operatic commodity.

Part and parcel of Žižek's concept of an ahistorical bar of the Real is an insistence on the validity of the idea of universality. In the preface to Opera's Second Death, Dolar and Zižek make their claim in no uncertain terms: "If we reduce a great work of art or science to its historical context we miss its universal dimension; apropos of Freud, it is . . . easy to describe his roots in the fin de siècle Vienna [sic]-much more difficult is demonstrating how this very specific situation enabled him to formulate universal theoretical insights" (pp. vii-viii). Is this not a throwback to the bad old days? Not only does it revive language- " great works of art?"- that has only just about been exorcised from our vocabulary, but it extends the reach of psychoanalytic theory in a deeply problematic way. Gary Tomlinson, for example, warns that the relevance of psychoanalytic theory is necessarily limited to the modern European subjectivity from which it emerged. ${ }^{34}$

\footnotetext{
${ }^{32}$ Nigel Reynolds, "Royal Opera Heading for a Box Office Tragedy," Telegraph (14 March 2001).

${ }^{33}$ Evans investigates the relevance of Bourdieu's ideas in the context of opera. Phantasmagoria, esp. pp. 97-103.

${ }^{34}$ And there is another limitation, one implied in the broader trajectory of Tomlinson's Metaphysical Song: if psychoanalytic theory is symptomatic of the same noumenalism that constitutes modern subjectivity, how then can it move beyond, or offer critical perspective on
}

Have we not learned to heed Jameson's exhorREVIEW tation: "always historicize?" And are we as musicologists not entitled to feel a little more weary than most on encountering such claims? Surely this is just the sort of sweeping claim that we have left behind, that the carefully historicized studies in Reading Critics Reading challenge.

Some clarification is in order here. For Žižek, the universal does not oppose the particular in the sense of obscuring and excluding it, but is in fact its founding negativity, and this is something that the particular disavows. So the most effective means of resisting "false universality" (the ideology of fixed universalism) is not to assert a preuniversal particularism - this still operates "within the terrain opened up by universality"-but to focus on the very process by which universality forms itself, seeking out the tension between the "open negativity" of "universality-in-becoming" and the actualized, fixed form it ultimately acquires. But once again we are in the realm of the a priori, theorizing a metalevel located somewhere beyond our capacity to conceptualize it in the first place. Surely, Butler counters, "the claim to universality always takes place in a given syntax, through a certain set of cultural conventions in a recognizable venue." ${ }^{\prime 35}$

For Žižek, the temporal form of this shortsightedness is historicism. Thus, in Opera's Second Death he warns against a historicization of attitudes to femininity that seeks to trace a shift from a matriarchal celebration of the feminine to a patriarchal disparagement. The opposition defined by sexual difference, Žižek observes, is not that between men and women but between humanity and its "feminine excess" (p. 182). These historicized attitudes, Žižek claims, are in fact two sides of the same

the modern subject? How can it illuminate, rather than merely repeat, the metaphysics that constitutes the modern subject, the metaphysics that modern opera stages? Searching for the possibility of a "postmetaphysical" opera, Tomlinson explores the late Nietzsche's reading of Carmen. The still metaphysically inclined assessment of music drama in The Birth of Tragedy he aligns with the "Lacanian Wagnerism" of Poizat and the "noumenal Wagnerism" of Abbate's Unsung Voices. See chap. 5 of Metaphysical Song, esp. p. 115.

${ }^{35}$ Contingency, pp. 102, 35. 
coin; each of them attempts to come to terms with "the unbearable, eternal antagonism of the feminine" (p. 182). It is not that the feminine is subject to history but that history itself emerges as a means of temporally displacing feminine excess. Here we are on familiar psychoanalytic ground, the kind of gender characterization that prompts Abbate to lament (with some justification) that it is always the feminine that finds itself aligned with excess (In Search of Opera, p. 52).

Žižek's desire to decenter history, rooted in a Hegelian dialectical historicity, leads him to emphasize the retroactive and the reflexive. Key to the structure of retroactive historicity is a backwards teleology in which history becomes what it always was: the "not-yet" (the ontologically incomplete) becomes the "alwaysalready," bypassing any middle stage of fulfillment in a mythical present. So, for example, Žižek writes approvingly of Michel Chion's reading of Wagner as an anticipation of the cinema, meaning not an evolutionary teleology in which "the lower stage already contains in nuce the seeds of the higher stage," but a futur antérieur in which cinema (with its vast representational apparatus) retroactively constructs music drama as meaningful. Allied to this retroactivity is a reflexivity that stresses not only the standard notion of the historian's role in constituting history, but also the dialectical understanding of the relationship between the universal and particular: "External difference is always an internal one ... the external limitation of a field of phenomena always reflects itself within this field, as its inherent impossibility fully to become itself." 36 By mobilizing this concept, Žižek argues, we move beyond the mere "external causality" highlighted by historicist contextualization and become aware of the constitutive tension built in to historical phenomena and not merely imposed on them from without. Apparently then, Richard Taruskin "misses the point" when he argues that Lady Macbeth of Mtsensk was banned for the wrong reason (i.e., for its sexual explicitness rather than in its "inhumane" legitimization of murderous Stalinism). Surely, Žižek contends, the

36Ibid., pp. 246, 237. "directly violent aspect of it had to be publicly disavowed" (Opera's Second Death, pp. 21215). In other words, we need to look beyond the immediate context (the sexual censorship) and recognize that the ban reflects the "external limitation."

Equally, Žižek argues, the mobilization of this reflexivity offers to dismantle "the standard formalist narrative of the autonomous growth of artistic styles" (p. 236). This would be a welcome gesture were it not for the fact that such formalist histories have long been discredited. ${ }^{37}$ Indeed—as the phrase "great work of art" might imply-Žižek actually threatens to reinstate that autonomy. So, for example, that Puccini could not finish Turandot is actually a "godsend" that prevented him from humiliating himself by adding his trademark "pathetic-tragic finale" in an era in which this had become an anachronism. In this way, Žižek argues, "the unfinished status of Turandot . . . obeys a deeper necessity" (p. 206). But by situating Turandot as an uncomfortable outsider left behind, caught in the march of modernism, does Žižek not actually reduce it to the status of an autonomous "work" caught in an equally autonomous, evolutionary aesthetic? Is this not precisely the formalist narrative that Žižek hoped to question? When it assumes that opera has entered a "posttragic" phase, does Žižek's claim not rely on some historicizing of its own? Žižek's "deeper necessity" is nothing more than the modernist ideology of compositional progress and originality, itself a product of nineteenth-century historicism. If we take our bearings not from the modernist canon but from the performance and distribution of operafrom opera houses, publishers, and the recording industry-we might see a different necessity emerge. And in the case of Lady Macbeth, Žižek's discussion is contextualized within a suspiciously linear, narrative understanding of what he calls a "long tradition" of fictional murderous wives stretching from Zola to film noir (p. 215). All of which inclines me to claim

\footnotetext{
${ }^{37}$ For a recent overview of some of the problems generated by concepts of "period" and "work," see Glenn Stanley, "Historiography," in The New Grove Dictionary of Music and Musicians, ed. Stanley Sadie and John Tyrell (2nd edn. London: Grove, 2001), vol. 11, pp. 552-58.
} 
that Žižek's historicity is constructed from the historicism that it excludes.

Nevertheless, the fusion of Lacanian psychoanalysis, German idealism, and Hegelian/ Marxist dialectics in Opera's Second Death makes for some breathtaking critique. Indeed, the spectacle of a theoretical apparatus so logical, so complete, and so self-assured that it might almost suggest an aesthetic object in itself is oddly familiar, hinting at the all-ornothing dogmatism of much music analysis. But, as the strident tone of the introduction makes clear, Opera's Second Death has polemic intent, and if it makes for uncomfortable reading, then so much the better. The authors' readiness to problematize some basic assumptions is more than welcome, and their declaration of love for this untimely cultural form might illuminate that which motivates so much of the scholarship reviewed here. Though Dolar and Žižek speak from the place of the opera lover-"How," they ask, "can one not love it" (p. ix)? - this is tough love, a critical confrontation. Theirs is the gratitude that Nietzsche expressed for Wagner, that "most instructive case." 38 At issue here is the capacity of opera to provoke difficult questions that extend well beyond the confines of the stage, the auditorium or the red carpet of the foyer. If the grave concerns for opera's well-being are justified, the debate it generates has never been healthier.

${ }^{38}$ Nietzsche, The Case of Wagner, in Basic Writings of Nietzsche, trans. and ed. Walter Kaufmann (New York: Modern Library, 1966; rpt. 1992), p. 648.

\begin{tabular}{|c|c|}
\hline \multirow{3}{*}{ ARTICLES } & IN OUR NEXT ISSUE (FALL 2003) \\
\hline & KirI Miller: Americanism Musically \\
\hline & Maribeth Clark: The Body and the Voice in La Muette de Portici \\
\hline & Boman Desai: The Boy Brahms \\
\hline REVIEW BY & Tobias Plebuch \\
\hline
\end{tabular}

